\title{
IDDEX OF ADVERIISEDS
}

4pi Analysis, Inc (www.4pi.com)

Advanced Microscopy Techniques(www.amtimaging.com)

CamScan USA (www.camscan-usa.com)

EBSciences (ebs@ebsciences.com).

EMPIX Imaging (www.empix.com)

Ernest F. Fullam (www.fullam.com)

ETS-Lindgren (www.ets-lindgren,com)

EUREM Meeting

FEI Company (www.feic.com)

Gatan Inc. (www.gatan.com)

Geller MicroAnalytical Lab (www.gellermicro.com)

Hitachi High Technologies America (www.hitachi-hhta.com)

IXRF Systems (www.ixrfsystems.com)

JEOL USA (www.jeol.com)

LabX (www.labx.com)

LEO Electron Microscopy (www.leo-usa.com)

M.E. Taylor Engineering (www.semsupplies.com)

Materials Analytical Services (MAS) (www.mastest.com)

McCrone Group (www.mccrone.com)
9 McGill University

19 Meiji Techno America (www.meijitechno.com)

31

.25

49

37

53

39

... 2

13

27

55

29

56

41

15

41

35

37

.

Micro Star Technologies (www. Microstartech.com) ...........................53

Pacific Nanotechnology (www.pacificnanotech.com) ........................47

Princeton Gamma Tech (www.pgt.com) ............................................. 4

Scientific Instruments and Applications (www.sia-cam.com) ..............41

ScopeTronix Quality Products (www.scopetronix.com) ......................4 49

SEMTech Solutions (www.semtechsolutions.com ................................. 33

SensIR Technologies (www.sensir.com/objective) ...................... 20, 21

Soft Imaging Systems Corporation (www.soft-imaging.com) ............... 7

Ted Pella, Inc. (www.tedpella.com) .................................................. 23

Thermo Electron Corp. (www.thermo.com/spectroscopy) ................... 5

Vital Image Technology (www.vitalimage.com) ............................... 46

XEI Scientific (www.SEMCLEAN.com) ….................................... 51

Employment Advertisements

ExxonMobil Research \& Engineering ............................................. 51

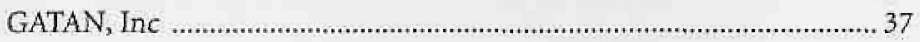

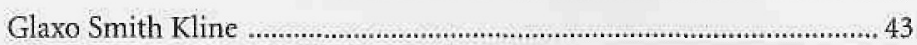

\section{SUBSORPTIOA REOUEST/OHDAGES}

\section{Individuals requesting subscriptions, or wishing to change/correct their current address, are requested to do so via our $w w w$ site: \\ http://www.microscopy-today.com}

\section{MICROSCOPY TODAY HAS NEW SUBSCRIPTION POLICIES}

We have redefined the "free to US" rule by adding microscopists in Canada and Mexico to the free eligibility list.

We have lowered our non-member, outside North America, subscription rate for the printed magazine from $\$ 80-\$ 110$ to \$35US per year-a sum that just covers postage and handling!

We have scanned back issues of MT into computer files, which we now make available for low-resolution free download, www site above, after a six-month delay. The entire issues are downloaded-advertisements and all.

- High resolution, $\mathrm{CD}$ format, complete volumes are available via airmail for the prices listed below. Note that a volume contains 6 issue for 2002 onwards and 10 issues for 1992 to 2001 . Contact editor to order.

Preferred payment is via credit card information when subscribing at the same www address. Bank transfer information available from editor. Checks in US\$, payable to "Microscopy Today," to the editor.

\begin{tabular}{|l|c|c|c|}
\hline \multirow{2}{*}{$\begin{array}{c}\text { IIIOROSOPY TOPNY } \\
\text { Subscription Schedule }\end{array}$} & $\begin{array}{c}\text { Purrent Printed } \\
\text { Issue }\end{array}$ & $\begin{array}{c}\text { Back Issue } \\
\text { Downloaded After } \\
\text { 6-Month Delay }\end{array}$ & $\begin{array}{c}\text { Back Issue Volume } \\
\text { High Resolution CD }\end{array}$ \\
\cline { 2 - 4 } Anyone in North America & Free & Free Low Resolution & $\begin{array}{c}\text { MSA member } \$ 20 / \text { volume } \\
\text { Non-MSA mbr. } \$ 35 / \text { vol. }\end{array}$ \\
\hline MSA member outside North America & Free & Free Low Resolution & $\$ 30 /$ volume \\
\hline Non-MSA member, outside North America & \$35/yr. per issue & Free Low Resolution & $\$ 45 /$ volume \\
\hline
\end{tabular}

